\title{
IMPROVING STUDENTS' READING COMPREHENSION THROUGH YOUTUBE AT GRADE VII OF SMPN 3 BUKIT BATU
}

\author{
Lismameriati Hutagaol \\ SMPN 3 Bukit Batu, Indonesia \\ hutagaollismam@gmail.com
}

\begin{abstract}
Learning during the pandemic that supports 21st century learning uses online learning and the media in the form of YouTube which has been prepared by the teacher in advance. The aim of this research was to improve the students' reading comprehension at grade VII of SMPN 3 Bukit Batu. This research used classroom action research in two cycles consisting of 2 lessons per cycle with a total of 27 students. The results of the research before the action obtained an average of 65.81 with the number of students completed the KKM were 13, classically $48 \%$. In the first cycle, learning was carried out by using youtube learning media so that an average of 70.2 was obtained with the number of students who completed were 20 people, with the percentage of classical completeness reaching $74.1 \%$. Meanwhile, in the second cycle, an average of 83.5 was obtained with the number of students who completed were 26 people with the percentage of classical completeness reached $96.3 \%$. The results of teacher observations found that the average cumulative results of the assessment on learning observation activities in the first cycle was 66.7 and increased in the second cycle by 91.7 . Thus, it was concluded that the use of youtube media was able to improve students' reading comprehension.
\end{abstract}

Keywords: youtube media, reading comprehension

\section{PENINGKATAN KEMAMPUAN MEMBACA PEMAHAMAN DENGAN MENGGUNAKAN MEDIA YOUTUBE SISWA KELAS VII SMPN 3 BUKIT BATU}

\section{ABSTRAK}

Pembelajaraan pada masa pandemic yang mendukung pembelajaran abad 21 yang menggunakan pembelajaran secara daring serta menggunakan media pembelajaran daring berupa youtube yang sudah dipersiapkan oleh guru terlebih dahulu dengan tujuan penelitian untuk meningkatkan kemampuan membaca pemahaman siswa kelas VII di SMPN 3 Bukit Batu. Metode penelitian ini menggunakan penelitian tindakan kelas dengan pelaksanaan pembelajaran dua siklus yang terdiri dari 2 pembelajaran setiap siklus dengan jumlah siswa 27 orang. Hasil penelitian sebelum tindakan dengan ratarata 65.81 dengan jumlah ketuntasan siswa 13 secara klasikal 48\%. Pada siklus I ini dilakukan pembelajaran dengan menggunakan media pembelajaran youtube sehingga didapat rata-rata 70.2 dengan jumlah siswa yang tuntas sebanyak 20 orang, dengan persentase ketuntasan klasikal mencapai $74.1 \%$, sedangkan pada siklus II diperoleh rata-rata sebesar 83.5 dengan jumlah siswa yang tuntas sebanyak 26 orang dengan pesentase ketuntasan klasikal mencapai 96.3\%. sedangkan hasil observasi guru Rata-rata hasil komulatif penilaian pada kegiatan observasi pembelajaran pada siklus I 66.7 dan meningkat pada siklus II sebesar 91.7 sehingga disimpulkan bahwa penggunaan media youtube mampu meningkatkan membaca pemahaman siswa.

Kata Kunci: media youtube, membaca pemahaman

\begin{tabular}{|c|c|c|}
\hline Submitted & Accepted & Published \\
\hline 08 Mei 2021 & 08 September 2021 & 17 September 2021 \\
\hline
\end{tabular}

\begin{tabular}{|l|c|r|}
\hline Citation & $:$ & $\begin{array}{r}\text { Hutagao, L. (2021). Improving Students' Reading Comprehension through Youtube at Grade VII of SMPN 3 Bukit Batu. } \\
\text { Jurnal PAJAR (Pendidikan dan Pengajaran), 5(5), 1461-1466. DOI : http://dx.doi.org/10.33578/pjr.v5i5.8497. }\end{array}$ \\
\hline
\end{tabular}

\section{PENDAHULUAN}

Perkembangan teknologi saat ini penggunaan bahasa menjadi semakin penting dan popular di berbagai bidang (Cheng, 2015). Kemampuan membaca pemahaman menjadi peran utama untuk mengetahu informasi yang akan disampaikan oleh teknologi kepada pembaca sehingga memberikan pengaruh yang besar terhadap perkembangan pembelajaran masa sekarang (Jin \& Qi, 2018). Pembelajaran membaca harus mendukung dasar-dasar untuk

memahami suatu teks yang mampu memberikan pemahaman kepada pembaca sehingga pembaca tidak mengalami kesulitan dalam menjawab dan menjelaskan atas informasi yang mereka dapatkan (Kurniaman, Noviana, Charlina, Simulyasih, Handayani, Sofyan, Zufriady, \& Septyanti, 2018). Membaca merupakan satu hal yang tidak akan terlepas dari dunia pendidikan. Untuk itu peseta didik wajib untuk mengerti dan memahami apa itu membaca. Ini semua di karenakan pada setiap 
aspek kehidupan masyarakat, kegiatan membaca akan terlibat lebih banyak dan lebih sering. Dengan ini membaca dapat menambah ilmu pengeatuhan siswa baik dikalangan pendidikan maupun dikalangan masyarakat (Pahrurrazi, Kurniaman, \& Alpusari, 2018).

Pembelajaran akan berubah sesuai dengan zaman dan kondisi yang mempengaruhi seperti saat ini Indonesia kini tengah dihadapkan dengan pandemi covid-19 yang tidak kunjung selesai. Coronavirus Disease 2019 atau sering disebut dengan covid-19 merupakan suatu virus jenis baru yang dapat menular. Berdasarkan pernyataan World Health Organization (WHO), covid-19 ini pertama kali ditemukan di Wuhan, Tiongkok, pada bulan Desember 2019 (Fajar, \& Puspasari, 2021). Wabah ini memberikan perubahan terhadap pembelajaran yang biasa digunakan secara tatap muka menjadi pembelajaran secara daring atau sering disebut dalam jaringan guna memutuskan mata rantai penyebaran Covid-19 (Hapsari, Ardianti, Ismaya, 2021). Perubahan kegiatan belajar ini memberikan tantangan baru bagi guru, siswa, dan orangtua yang bervariasi untuk memberikan pembelajaran yang efektif serta memberikan pembelajaran yang bermakna (Novianti, Puspitasari, \& Maria, 2021). Sehingga guru harus lebih kreatif dengan membuat media pembelajaran membaca sehingga media youtube lebih efektif bila diterapkan sebagai pembelajaran yang sesuai pada masa pandemic ini.

Media youtube merupakan media yang berkategori kepada audio visual yang digunakan dalam proses pembelajaran (Munjiatun, Guslinda, Kurniaman, Noviana, and Ramadhan, 2021). sebagai perantara untuk menyampaikan pesan guru kepada siswa yang dilakukan pada pembelajaran membaca pemahaman. Membaca adalah interaksi dengan bahasa yang telah diterjemahkan ke dalam bentuk tulisan. Jika seseorang dapat berinteraksi dengan bahasa yang telah ditafsirkan dalam bentuk tulisan, orang tersebut dianggap memiliki keterampilan membaca (Kurniaman, et.al, 2018). Masa wabah ini sangat mempengaruhi perubahan pola hidup yang memberikan gambaran siswa ingin lebih gampang dan mudah untuk mencari sesuatu atau membaca referensi yang mereka inginkan (Azimah, \& Kurniaman, 2019). Membaca juga memiliki dampak mendalam pada kualitas pembangunan budaya membaca pada bangsa dan negara. Masalah utama yang terdapat pada siswa adalah mengenai beban waktu yang diberikan oleh sekolah (Kurniaman, Noviana, Hermita, \& Charlina, 2019). Model pembelajaran yang direkomendasikan oleh Kurikulum 2013 menyatakan proses pembelajaran pada satuan pendidikan harus dilaksanakan secara interaktif, inspirasional, menyenangkan, menantang, memotivasi siswa untuk berpartisipasi aktif, dan memberikan ruang yang cukup untuk inisiatif, kreativitas, dan kemandirian sesuai bakat, minat, dan pengembangan fisik dan psikologis siswa (Agustina, \& Naphiah, 2021).

\section{METODE PENELITIAN}

Metode penelitian yang digunakan dalam penelitian ini menggunakan penelitian tindakan kelas yang digunakan untuk memperbaiki pembelajaran yang sudah ada sehingga memberikan perubahan yang terjadi pada kelas yang diajarnya (Arikunto, 2018). Penelitian in adalah penelitian tindakan kelas, PTK adalah suatu pencermatan terhadap kegiatan belajar berupa sebuah tindakan, yang sengaja dimunculkan dan terjadi dalam sebuah kelas dengan tujuan perbaikan kinerja guru. Penelitian ini dilaksanakan selama dua siklus (Kurniaman, \& Huda, 2018). 


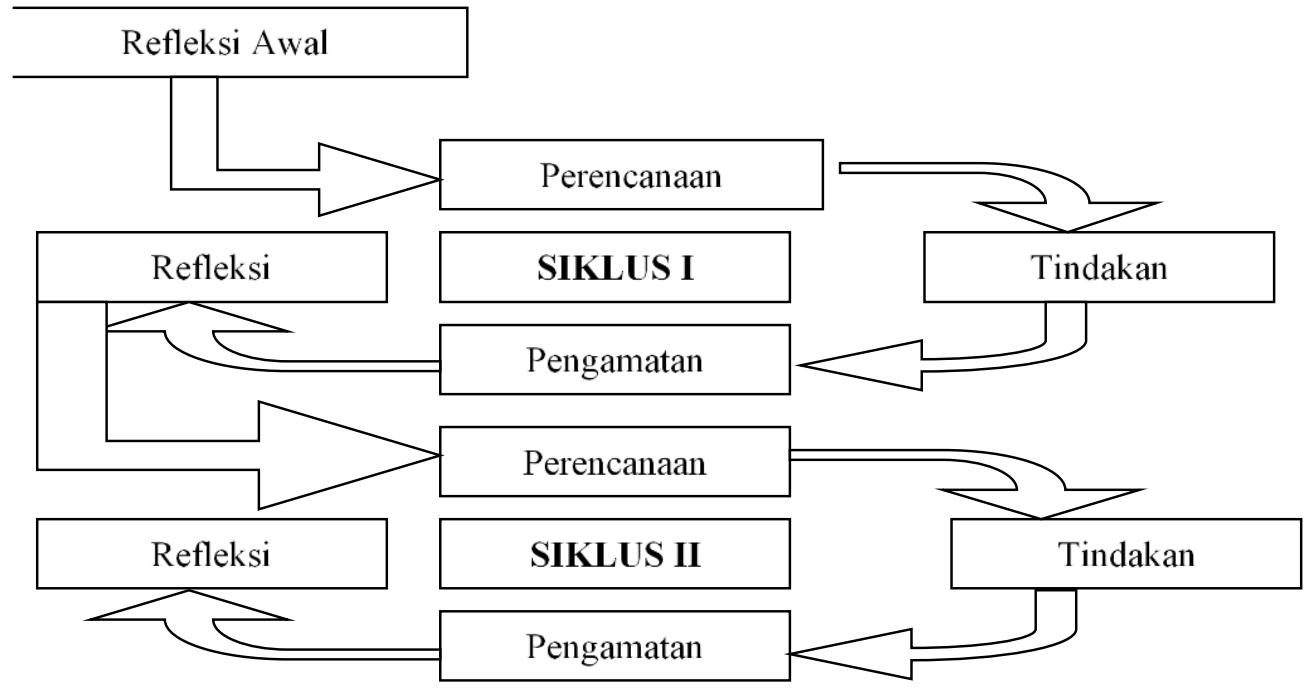

\section{Gambar 1. Siklus Penelitian Tindakan Kelas}

Penelitian ini dilakukan di sekolah SMPN 3 Bukit Batu di kelas VII dengan jumlah siswa 27 orang yang terdiri dari 11 orang laki-laki, dan 16 orang perempuan, dengan waktu penelitian dilakukan pada bulan Maret- Juni 2021. Teknik pengumpulan dalam data penelitian ini menggunakan 1) Tes: digunakan untuk mengetahui hasil belajar siswa setelah dilaksanakan tindakan. Tes tertulis yang dilaksanakan berbentuk essay, yang dibuat sesuai dengan materi pembelajaran yang dilaksanakan. 2) Observasi: untuk mengumpulkan data aktifitas siswa dan guru selama proses pembelajaran dengan menggunakan lembar pengamatan. Teknik analisis data penelitian ini menggunakan penghitungan rata-rata kemampuan guru dan kemampuan membaca pemahaman siswa dengan menggunakan matematika, serta mengolah data observasi menjadi suatu data penelitian untuk mengetahui peningkatan guru dalam mengajar atau melihat pengaruh media youtube sebagai salah satu media yang digunakan untuk proses pembelajaran.

\section{HASIL DAN PEMBAHASAN}

Penelitian ini dilakukan di SMPN 3 Bukit Batu di kelas VII dengan membagi menjadi 2 siklus yang terdiri setiap siklus 2 (dua) pembelajaran dengan menggunakan media youtube yang digunakan dalam pembelajaran. Media youtube ini dibuat oleh guru dengan menyusuaikan dengan kompetensi dasar, dan indikator pada setiap pertemuan dengan memberikan teks bacaan sehingga siswa akan mencari teks yang sudah disiapkan link pada media youtube. Pembelajaran terlebih dahulu dibuka melalui zoom meeting dengan memberikan motivasi pembelajaran dan penyampaian tujuan pembelajaran. Selanjutnya memberikan media youtube yang berisikan perintah dalam melaksanakan pembelajaran membaca pemahaman yang akan disampaikan. Untuk melihat kemampuan siswa dalam membaca pemahaman akan terlihat pada tabel 1 .

\begin{tabular}{cccc}
\hline \multicolumn{4}{c}{ Tabel 1. Kemampuan Membaca Pemahaman Siswa } \\
\hline Tindakan & Rata-rata & $\begin{array}{c}\text { Jumlah yang } \\
\text { Tuntas }\end{array}$ & Jumlah Klasikal \\
\hline Sebelum Tindakan & 65.81 & 13 & $48 \%$ \\
Siklus I & 70.2 & 20 & $74.1 \%$ \\
Siklus II & 83.5 & 26 & $96.3 \%$ \\
\hline
\end{tabular}


Terlihat pada tabel 1 kemampuan membaca pemahaman siswa di SMPN 3 Bukit Batu di kelas VII sebelum tindakan dengan ratarata 65.81 dengan jumlah ketuntasan siswa 13 secara klasikal $48 \%$. Pada siklus I ini dilakukan pembelajaran dengan menggunakan media pembelajaran youtube sehingga didapat rata-rata 70.2 dengan jumlah siswa yang tuntas sebanyak 20 orang, dengan persentase ketuntasan klasikal mencapai $74.1 \%$, sedangkan pada siklus II diperoleh rata-rata sebesar 83.5 dengan jumlah siswa yang tuntas sebanyak 26 orang dengan pesentase ketuntasan klasikal mencapai 96.3\%. Dari data yang hasil penelitian yang digambarkan pada tabel 1 terlihat ada peningkatan dalam proses pembelajaran dari siklus I dan siklus II untuk lebih jelas bisa dilihat pada grafik di bawah ini.

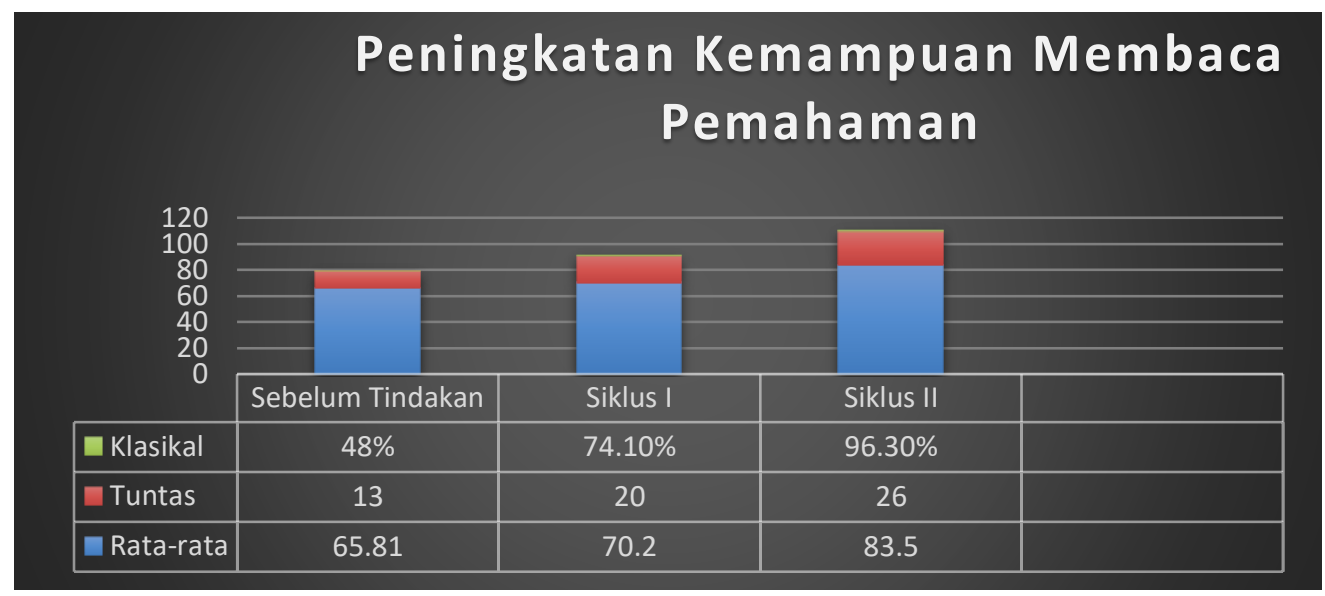

Gambar 2. Peningkatan Kemampuan Membaca Pemahaman

Untuk melihat kemampuan guru dalam mengajar dengan menggunakan media youtube dengan penilaian dari observer yang sudah lebih pengalaman di dalam proses pembelajaran sehingga mampu menilai kemampuan guru.
Aktivitas guru memberikan gambaran kesuksesan dalam pembelajaran sehingga memberikan pengaruh terhadap kemampuan membaca pemahaman siswa. Dengan hasil yang terlihat pada tabel 2.

Tabel 2. Nilai Observasi Guru Siklus I dan Siklus II

\begin{tabular}{|c|c|c|c|}
\hline \multirow[t]{2}{*}{ NO } & \multirow[t]{2}{*}{ KOMPONEN } & \multirow{2}{*}{$\begin{array}{l}\text { SIKLUS I } \\
\text { SKOR }\end{array}$} & \multirow{2}{*}{$\frac{\text { SIKLUS II }}{\text { SKOR }}$} \\
\hline & & & \\
\hline 1. & $\begin{array}{l}\text { Guru membuka dan menjelaskan tentang } \\
\text { tujuan pembelajaran }\end{array}$ & 3 & 4 \\
\hline 2. & Guru memberikan motivasi pembelajaran & 2 & 3 \\
\hline 3. & $\begin{array}{l}\text { Guru mengirim media pembelajaran } \\
\text { youtube }\end{array}$ & 3 & 4 \\
\hline 4. & $\begin{array}{l}\text { Guru menjelaskan tentang materi yang ada } \\
\text { di dalam media youtube }\end{array}$ & 2 & 4 \\
\hline 5. & $\begin{array}{l}\text { Guru menjelaskan dan memberikan } \\
\text { penguatan dalam pembelajaran }\end{array}$ & 3 & 3 \\
\hline 6. & $\begin{array}{l}\text { Guru bersama dengan siswa memberikan } \\
\text { simpulan pembelajaraan }\end{array}$ & 3 & 4 \\
\hline & Jumlah & 16 & 22 \\
\hline & Rata-rata & 66.7 & 91.7 \\
\hline
\end{tabular}


Data dari tabel 2 hasil dari penilaian observer dalam pelaksanaan pembelajaran dengan menggunakan media youtube terlihat pada komponen guru membuka dan menjelaskan tentang tujuan pembelajaran pada siklus I sudah baik akan tetapi ada kendala-kendala yang muncul saat guru memberikan penjelasan terlihat kaku ini disebabkan karena secara daring sehingga ada beberapa yang belum terbiasa dengan memberikan penjelasan. Kekurangan dalam komponen pertama setelah dilakukan refleksi pada siklus I maka kesalahan- kesalahan yang ditemukan pada akhir pertemuan diperbaiki pada siklus II dengan memberikan penjelasan yang lebih jelas lagi sehingga di dapat nilai sangat baik.

Komponen kedua guru memberikan motivasi pembelajaran pada siklus I masih terkendala sekali sehingga mendapatkan nilai cukup karena guru memberikan motivasi yang singkat sehingga siswa kurang merespon apa yang disampaikan oleh guru. Kelemahan dan kekurangan dalam pembelajaran pada komponen kedua diperbaiki sehingga mendapatkan nilai baik setelah dilakukan refleksi. Komponen ketiga guru mengirim media pembelajaran yotube secara daring mendapatkan nilai baik, dan pada siklus II mendapatkan nilai sangat baik. Komponen guru dalam menjelaskan tentang materi yang ada di dalam youtube dengan nilai cukup sedangkan pada siklus II dengan nilai sangat baik.

Komponen guru menjelaskan dan memberikan penguatan dalam pembelajaran pada siklus I dengan hasil penilaian dengan nilai baik dan pada siklus II dengan nilai baik juga dalam komponen ini masih belum ada perubahan dalam proses pembelajaran. Komponen terakhir guru bersama dengan siswa memberikan simpulan pembelajaran pada siklus I dengan nilai baik sedangkan pada siklus II dengan nilai sangat baik. Rata-rata hasil komulatif penilaian pada kegiatan observasi pembelajaran pada siklus I 66.7 dan meningkat pada siklus II sebesar 91.7.

Salah satu yang menarik dari pembelajaran dengan menggunakan media video youtube adalah tayangan video yang didalamnya ada efek teks, gambar bergerak, efek suara yang mengandung instruksi pembelajaran dan animasi. Animasi yang disertai instruksi pembelajaran yang dihadirkan dapat memvisualisasikan konsep yang abstrak menjadi lebih nyata sehingga membuat siswa termotivasi untuk belajar. Hal menarik lainnya yang menyebabkan motivasi belajar siswa dengan menggunakan media video youtube lebih tinggi dibandingkan dengan media riil dan media charta karena, bagi beberapa sekolah media video youtube adalah media baru yang interaktif yang sarat dengan Information Teknology (IT) sehingga menimbulkan rasa ingin tahu yang dalam (Iwantara, Sadia, \& Suma, 2014). Mengajarkan membaca harus memberikan pembelajaran yang menarik minat siswa dalam membaca (Kurniaman, Oktari, \& Pahrurazi, 2019). sehingga mereka mampu membaca secara keseruluhan bacaan shingga mampu meningkatkan kemampuan membaca pemahaman siswa.

\section{SIMPULAN DAN REKOMENDASI}

Simpulan dalam penelitian ini adalah penggunaan media youtube dalam pembelajaran membaca pemahaman pada siswa kelas VII efektif digunakan dalam meningkatkan kemampuan membaca pemahaman yang terlihat pada hasil kemampuan siswa setiap siklus pembelajaran yang didapat dengan memberikan tes sebagai alat untuk mengumpulkan data hasil penelitian. Saran dalam penelitian ini adalah guru harus mempersiapkan secara matang media pembelajaran youtube dan memberikan isi yang semenarik mungkin untuk merangsang pembelajaran siswa.

\section{DAFTAR PUSTAKA}

Azimah, R., \& Kurniaman, O. (2019). Implementasi Gerakan Literasi Sekolah dalam Pembelajaran di Kelas Tinggi. Jurnal PAJAR (Pendidikan dan Pengajaran), 3(4), 934-947. DOI: http://dx.doi.org/10.33578/pjr.v3i4.7567

Agustina, W., \& Naphiah, S. (2021). Project Based Learning with Peer Instruction Flipped Classroom Design to Improve Critical Thinking Skills and Science Literacy. Jurnal PAJAR (Pendidikan dan Pengajaran), 5(2), 442-448. DOI : 
Jurnal PAJAR (Pendidikan dan Pengajaran)

Volume 5 Nomor 5 September 2021 | ISSN Cetak : 2580 - 8435| ISSN Online : 2614 - 1337

DOI : http://dx.doi.org/10.33578/pjr.v5i5.8497

http://dx.doi.org/10.33578/pjr.v5i2.8214

Arikunto, S. (2008). Penelitian Tindakan Kelas. Jakarta: Bumi Aksara

Cheng, X. (2015). The SPSS Analysis of Higher Vocational English, Heihe Journal, (9), 99-101.

Fajar, Y. M. D., \& Puspasari, D. (2021). The Effectivenes ef E-Learning as a Learning Media in Archiving Subject at SMKN 2 Buduran Sidoarjo during the Covid-19 Pandemic. Jurnal PAJAR (Pendidikan dan Pengajaran), 5(4), 1043-1064. DOI http://dx.doi.org/10.33578/pjr.v5i4.8403

Hapsari, R.W., Ardianti, S.D., Ismaya, E.A. (2021). Parents' Role in Assisting Children in Online Learning during Covid- 19 Pandemic. Jurnal PAJAR (Pendidikan dan Pengajaran), 5(3), 656662. DOI http://dx.doi.org/10.33578/pjr.v5i3.8310

Iwantara, I. W., Sadia, I. W., \& Suma, I. K. (2014). Pengaruh Penggunaan Media Video Youtube Dalam Pembelajaran IPA Terhadap Motivasi Belajar Dan Pemahaman Konsep Siswa. e-Journal Program Pascasarjana Universitas Pendidikan Ganesha Program Studi IPA, 4, 1-14.

Jin, Y., \& Qi, X. (2018). The SPSS-based Analysis of Reading Comprehension-Take Grade Eight English Mid-term Test for Example. Journal of Language Teaching and Research, 9(5), pp. 939-945.

Kurniaman, O., Noviana, E., Charlina, C., S. B. Simulyasih, N., Handayani, H. D., Sofyan, N. S., Zufriady, Z., \& Septyanti, E. (2018). Why Should Primary Teachers Develop Learning Material by Directed Reading Thinking Activity (DRTA) Strategy?: 4-D Model. Advanced Science Letters, 24(11), 8389-8391.

Kurniaman, O., Charlina., \& Noviana, E. (2018). Implementation DRTA Strategi for Elementary School. Beau Bassin:
Lambret Academic Publishing.

Kurniaman, O., Noviana, E., Hermita, N., \& Charlina, C. (2019). Pengaruh Strategi Membaca Direct Reading Thinking Activity (Drta) Terhadap Siswa Sekolah Dasar. SEJ (School Education Journal), 9(3), 221-230.

Kurniaman, O., \& Huda, M. N. (2018). Penerapan Strategi Bercerita Untuk Meningkatkan Keterampilan Menyimak Siswa Kelas III SD Muhamadiyah 6 Pekanbaru. Primary : Jurnal Pendidikan Guru Sekolah Dasar, 7(2), 249-255.

Kurniaman, O., Oktari, C., \& Pahrurazi, P. (2019). The Implementation of Teaching Materials Reading Graphic Organizers in Elementary Schools. Lensa: Kajian Kebahasaan, Kesusastraan, dan Budaya, 9(2), 105-119.

Munjiatun, M., Guslinda, G., Kurniaman, O., Noviana, E., and Ramadhan, M. (2021). Child Comic Development With The Themes Of Prevention Covid-19: Validation Analysis. METODIK DIDAKTIK Jurnal Pendidikan Ke-SDan, 16 (2), 88-94.

Novianti, R., Puspitasari, E., \& Maria, I. (2021). Parents' Involvement in Children's Learning Activities during the Covid-19 Pandemic. Jurnal PAJAR (Pendidikan dan Pengajaran), 5(2), 384-390. DOI : http://dx.doi.org/10.33578/pjr.v5i2.8220

Pahrurrazi, P., Kurniaman, O., \& Alpusari, M. (2018). Analisis Minat Baca Siswa Di Perpustakaan SDN 37 Pekanbaru. Jurnal PAJAR (Pendidikan dan Pengajaran), 2(6), 872-876. 